\title{
ANALISIS KUAT TEKAN BETON K.200 DENGAN MENGGUNAKAN LIMBAH PECAHAN BATU BATA SEBAGAI PENGGANTI AGREGAT KASAR
}

\author{
Ligal Sebastian $^{1)}$, Achmad Syarifudin ${ }^{2)}$, Alamsyah ${ }^{3)}$ \\ ${ }^{1)}$ Dosen Universitas Palembang, ${ }^{2)}$ Dosen Universitas Bina Darma Palembang, \\ ${ }^{3)}$ Mahasiswa Universitas Palembang) \\ e-mail : ${ }^{2)}$ syarifachmad6080@yahoo.co.id
}

\begin{abstract}
ABSTRAK
Penggunaan material limbah pecahan batu bata dalam campuran beton di Indonesia masih belum umum namun sudah mulai banyak digunakan antara lain untuk pengurukan, lapisan pondasi jalan dan lain-lain. Hal ini mungkin disebabkan bahan baku seperti agregat kasar mudah didapat. Padahal cepat atau lambat material akan semakin habis sehingga menyebabkan material dari tahun ke tahun akan semakain mahal. Penelitian dan pengujian beton ini bertujuan untuk mengetahui kuat tekan beton dengan memanfaatkan limbah pecahan batu bata dengan sumber agregat halus (pasir) dari sungai musi, sedangkan agregat kasar (batu pecah/split) didapat dari lahat. Pada penelitian ini beda uji dicetak dengan menggunakan kubus baja ukuran $15 \mathrm{~cm} \times 15 \mathrm{~cm} \times 15 \mathrm{~cm}$ dan direndam, masing-masing umur beton yaitu 7 hari, 14 hari, 21 hari dan 28 hari dengan pengujian kuat tekan beton. Pada campuran beton K.200 tersebut dibuat campuran pengganti agregat kasar yang berfariasi yaitu dengan limbah pecahan batu bata $0 \%$ (normal), limbah pecahan batu bata $10 \%$, limbah pecahan batu bata $20 \%$ dan limbah pecahan batu bata $30 \%$ dengan cara mengurangi persentase dari agregat kasar (split). Beton yang mencapai umur 28 hari karena pada umur ini menurut PBI 1974, kekuatan beton telah mencapai 100\%. Dari hasil uji kuat tekan yaitu pada beton normal (limbah pecahan batu bata $0 \%$ ) dengan umur 28 hari didapat kuat tekan beton sebesar $199,27 \mathrm{~kg} / \mathrm{cm}^{2}$, pada beton kadar limbah pecahan batu bata 10\% dengan umur 28 hari didapat kuat tekan beton sebesar $179,65 \mathrm{~kg} / \mathrm{cm}^{2}$, pada beton kadar limbah pecahan batu bata $20 \%$ dengan umur 28 hari didapat kuat tekan beton sebesar $172,10 \mathrm{~kg} / \mathrm{cm}^{2}$, dan pada beton kadar limbah pecahan batu bata $30 \%$ dengan umur 28 hari didapat kuat tekan beton sebesar $170,59 \mathrm{~kg} / \mathrm{cm}^{2}$.
\end{abstract}

Kata Kunci : Kuat Tekan Beton, agregat halus, agregat kasar, limbah pecahan batu bata.

\section{PENDAHULUAN}

\section{A. Latar Belakang}

Beton adalah suatu campuran antara semen sebagai bahan perekat, air sebagai bahan pembantu reaksi kimia selama proses pengerasan dan perawatan beton berlangsung, dan agregat sebagai bahan pengisi yang menyebabkan terjadinya suatu hubungan erat antara bahan bahan tersebut. Banyaknya jumlah penggunaan beton dalam konstruksi bangunan gedung, jalan, jembatan, dermaga dan lain-lain mengakibatkan peningkatan kebutuhan material beton, sehingga mendorong penambangan batuan sebagai salah satu bahan pembentuk beton secara besarbesaran yang menyebabkan turunya jumlah sumber alam yang tersedia untuk keperluan pembetonan (Suharwanto, 2005). Penggunaan material limbah pecahan batu bata dalam campuran beton di Indonesia masih belum umum namun sudah mulai banyak digunakan antara lain untuk pengurukan, lapisan pondasi jalan dan lain-lain. Hal ini mungkin disebabkan bahan baku seperti agregat kasar mudah didapat. Padahal cepat atau lambat material akan semakin habis sehingga menyebabkan material dari tahun ke tahun akan semakain mahal. Terutama agregat kasar atau kerikil yang hampir $78 \%$ menjadi bahan pengisi utama campuran beton (Astanto, 2001).

\section{B. Tujuan Penelitian}

Adapun tujuan penelitian ini adalah :

1. Untuk mengetahui besarnya kuat tekan beton normal K.200 dengan beton 
memakai bahan limbah pecahan batu bata sebagai pengganti agregat kasar dalam campuran beton.

2. Untuk mengetahui pengaruh pecahan batu bata sebagai bahan pengganti sebagian agregat kasar dengan variabel tertentu terhadap uji kuat tekan beton.

\section{Manfaat Penelitian}

Hasil penelitian ini dapat menyumbang pemikiran terhadap pemecahan masalah yang berkaitan dengan pengolahan limbah pecahan batu bata yang tidak dapat digunakan sebagai bahan bangunan dan menjadi limbah yang di buang.

\section{Rumusan Masalah}

1. Bagaimana pengaruh limbah pecahan batu bata sebagai pengganti agregat kasar tersebut terhadap kuat tekan beton.

2. Bagaimana pengaruh perbandingan beberapa variabel campuran limbah pecahan batu bata sebagai pengganti agregat kasar terhadap kuat tekan.

3. Batasan masalah didalam penelitian ini penulis membatasi ruang lingkup pekerjaan pengujian - pengujian bahan material dan benda uji kuat tekan di laboratorium.

\section{E. Batasan Masalah}

Penelitian dilakukan terhadap beton dengan membandingkan antara beton normal dengan beton yang menggunakan limbah pecahan batu bata sebagai pengganti agregat kasar, perlakuan yang diambil pada penelitian ini sebanyak 4 perbandingan yaitu ;

1. Beton normal dengan mutu K.200

2. Beton dengan menggunakan campuran limbah pecahan batu bata sebagai pengganti agregat kasar sebesar $10 \%$.

3. Beton dengan menggunakan campuran limbah pecahan batu bata sebagai pengganti agregat kasar sebesar $20 \%$.

4. Beton dengan menggunakan campuran limbah pecahan batu bata sebagai pengganti agregat kasar sebesar 30\%.

\section{TINJAUAN PUSTAKA}

\section{A. Beton}

Beton merupakan salah satu bahan konstruksi yang telah umum digunakan untuk bangunan gedung, jembatan, jalan, dan lain- lain. Beton merupakan satu kesatuan yang homogen. Beton ini didapatkan dengan cara mencampur agregat halus (pasir), agregat kasar (kerikil), atau jenis agregat lain dan air, dengan semen portland atau semen hidrolik yang lain, kadang-kadang dengan bahan tambahan (additif) yang bersifat kimiawi ataupun fisikal pada perbandingan tertentu, sampai menjadi satu kesatuan yang homogen. Campuran tersebut akan mengeras seperti batuan. Pengerasan terjadi karena peristiwa reaksi kimia antara semen dengan air.

Beton yang sudah mengeras dapat juga dikatakan sebagai batuan tiruan, dengan rongga-rongga antara butiran yang besar (agregat kasar atau batu pecah), dan diisi oleh batuan kecil (agregat halus atau pasir), dan pori-pori antara agregat halus diisi oleh semen dan air (pasta semen). Pasta semen juga berfungsi sebagai perekat atau pengikat dalam proses pengerasan, sehingga butiran-butiran agregat saling terekat dengan kuat sehingga terbentuklah suatu kesatuan yang padat dan tahan lama.

Membuat beton sebenarnya tidaklah sederhana hanya sekedar mencampurkan bahan-bahan dasarnya untuk membentuk campuran yang plastis sebagaimana sering terlihat pada pembuatan bangunan sederhana. Tetapi jika ingin membuat beton yang baik, dalam arti memenuhi persyaratan yang lebih ketat karena tuntutan yang lebih tinggi, maka harus diperhitungkan dengan seksama cara-cara memperoleh adukan beton segar yang baik dan menghasilkan beton keras yang baik pula. Beton segar yang baik ialah beton segar yang dapat diaduk, dapat diangkut, dapat dituang, dapat dipadatkan, tidak ada kecenderungan untuk terjadi pemisahan kerikil dari adukan maupun pemisahan air dan semen dari adukan. Beton keras yang baik adalah beton yang kuat, tahan lama, kedap air, tahan aus, dan kembang susutnya kecil (Tjokrodimulyo 1996 : 2)

\section{B. Agregat}

Agregat merupakan butiran mineral alami atau buatan yang berfungsi sebagai bahan pengisi dari campuran beton. Agregat menempati $\pm 70 \%$ volume beton, sehingga sangat berpengaruh terhadap sifat ataupun kualitas beton, sehingga pemilihan agregat merupakan bagian yang sangat penting dalam pembuatan beton. 
Menurut Tjokrodomulyo (1992) agregat umumnya digolongkan menjadi 3 kelompok, yaitu :

1. Batu untuk besar butiran lebih dari $40 \mathrm{~mm}$.

2. Kerikil untuk besar butiran antara $5 \mathrm{~mm}$ sampai $40 \mathrm{~mm}$.

3. Pasir untuk butiran antara $0,15 \mathrm{~mm}$ sampai $5 \mathrm{~mm}$.

Jenis-Jenis agregat yang digunakan/dipakai sebagai bahan susun beton adalah agregat halus dan agregat kasar.

\section{Semen Portland}

Semen portland ialah semen hidrolis yang dihasilkan dengan cara menghaluskan klinker yang terdiri dari silikat-silikat kalsium yang bersifat hidrolis dengan gips sebagai bahan tambahan (PUBI-1982). Fungsi semen ialah untuk merekatkan butir-butir agregat agar terjadi suatu massa yang kompak atau padat, selain itu juga untuk mengisi rongga diantara butiran-butiran agregat.

Semen portland dibuat melalui beberapa langkah, sehingga sangat halus dan memiliki sifat adhesif maupun kohesif. Semen diperoleh dengan membakar karbonat atau batu gamping) dan argillaceous (yang mengandung aluminia) dengan perbandingan tertentu. Bahan tersebut dicampur dan dibakar dengan suhu $1400^{\circ} \mathrm{C}-1500^{\circ} \mathrm{C}$ dan menjadi klinker. Setelah itu didinginkan dan dihaluskan sampai seperti bubuk. Lalu ditambahkan gips atau kalsium sulfat (CaSO4) kira-kira $2-4 \%$ persen sebagai bahan pengontrol waktu pengikatan. Bahan tambah lain kadang ditambahkan pula untuk membentuk semen khusus misalnya kalsium klorida untuk menjadikan semen yang cepat mengeras. Semen biasanya dikemas dalam kantong $40 \mathrm{~kg}$ / $50 \mathrm{~kg}$.

\section{Air}

Air merupakan bahan dasar yang sangat penting dalam pembuatan beton. Air diperlukan untuk bereaksi dengan semen serta menjadi bahan pelumas antara butir-butir agregat sehingga mudah dipadatkan. Di dalam penggunaannya, air tidak boleh terlalu banyak karena akan menyebabkan menurunnya kekuatan beton itu sendiri.

Air yang digunakan untuk pembuatan beton harus bersih dan tidak mengandung minyak, tidak mengandung alkali, garam- garaman, zat organis yang dapat merusak beton atau baja tulangan. Air tawar yang biasanya diminum baik air diolah oleh PDAM atau air dari sumur yang tanpa diolah dapat digunakan untuk membuat beton.

\section{E. Rencana Campuran Beton}

Perencanaan campuran beton adalah suatu cara untuk menentukan perbandingan bahan-bahan campurannya sedemikian sehingga untuk keadaan tertentu dihasilkan beton dengan sifat - sifat yang diisyaratkan dan dengan harga ekonomis.

SK SNI T-15-1990-03 tentang tata cara rencana campuran beton normal mengemukakan persyaratan umum yang harus dipenuhi dalam hal perencanaan campuran adalah sebagai berikut :

1. Proporsi campuran beton harus menghasilkan beton yang memenuhi persyaratan:

a. Kekentalan yang memungkinkan pekerjaan beton ( Penuangan / pemadatan dan perataan ) dengan mudah dapat mengisi acuan dan menutup permukaan secara serba sama ( homogen )

b. Keawetan

c. Kuat tekan

d. Ekonomis

2. Beton yang dibuat harus menggunakan bahan agregat normal tanpa bahan tambahan.

Dalam perencanaan beton harus dipenuhi persyaratan :

a. Perhitungan perencanaan campuran beton harus didasarkan pada data sifat-sifat bahan yang akan dipergunakan dalam produksi beton.

b. Susunan campuran beton yang diperoleh dari perencanaan ini harus dibuktikan melalui campuran coba yang menunjukkan bahwa proporsi tersebut dapat memenuhi kekuatan beton yang diisyaratkan.

\section{F. Kuat Tekan (fc)}

Kuat tekan beton yang diisyaratkan fc adalah kuat tekan beton yang ditetapkan oleh perencana struktur (benda uji berbentuk kubus dengan ukuran $15 \mathrm{~cm}$ x $15 \mathrm{~cm}$ x $15 \mathrm{~cm}$ ), dipakai dalam perencanaan struktur beton, dinyatakan dalam Mega Paskal (Mpa) atau dinyatakan dalam Karakteristik $\left(\mathrm{Kg} / \mathrm{cm}^{2}\right)$. 


\begin{abstract}
Nilai kuat tekan beton didapatkan melalui tata cara pengujian standar, menggunakan mesin uji dengan cara memberikan beban tekan bertingkat dengan kecepatan peningkatan beban tertentu atas benda uji kubus beton (ukuran $15 \mathrm{~cm}$ x $15 \mathrm{~cm}$ x $15 \mathrm{~cm})$ sampai hancur. Tata cara pengujian yang dipakai adalah standar DOE (Department of Environment), untuk kondisi di Indonesia telah diadakan penyesuaian pada besarnya variasi kuat tekan beton. Menurut Dipohusodo (1994 : 7), kuat tekan masing-masing benda uji ditentukan oleh tegangan tekan tertinggi (fc) yang dicapai benda uji umur 28 hari akibat beban tekan selama percobaan.

Menurut Tjokrodimuljo (1996 : 59), faktor-faktor yang sangat mempengaruhi kekuatan beton antara lain faktor air semen, umur beton, jenis semen, jumlah semen, dan sifat agregat.
\end{abstract}

\section{METODOLOGI PENELITIAN}

\section{A. Persiapan Peralatan}

Sebelum Penelitian dilakukan, perlu adanya persiapan peralatan dan bahan. Peralatan yang digunakan terdiri dari :

1. Timbangan, alat untuk menimbang benda uji, agregat halus dan kasar dengan ketelitian $0,3 \%$.

2. Specific Gravity, alat ini digunakan untuk menentukan berat jenis agregat halus dan kasar dengan ketelitian 0,1\%.

3. Talam-talam, alat untuk mengeringkan material.

4. Pan Alumunium / Cawan

5. Cetakan Beton dengan ukuran $15 \times 15$ x $15 \mathrm{~cm}$

6. Piknometer (Labu Ukur)

7. Mesin Penggetar

8. Centong

9. Kuas

10. Ember Plastik

11. Mistar Perata

12. Alat pengaduk campuran beton

13. Meteran

14. Bak Adukan, alat untuk tempat adukan terbuat dari plat yang datar dari bahan sejenis metal, kedap air dan mampu menahan beban adukan.

15. Oven yang dilengkapi pengatur suhu, alat yang digunakan untuk mengeringkan agregat halus dan agregat kasar

16. Satu set saringan / ayakan, untuk memeriksa agregat halus dan kasar.
17. Kerucut Terpancung, alat untuk mengukur kadar air pada campuran beton. Tongkat (penusuk) terbuat dari baja tahan karat gunanya adalah untuk pemadat.

18. Mesin Uji Kuat Tekan, alat untuk memeriksa kuat tekan beton.

\section{B. Persiapan Bahan-Bahan Penelitian}

Bahan-bahan yang dibutuhkan untuk penelitian ini antara lain:

1. Semen Portland type I ex. Baturaja

2. Agregat halus (Pasir) ex. sungai musi

3. Agregat kasar (Split) ex. Lahat

4. Limbah pecahan kaca

5. Air adalah air bersih yang ada di laboratorium Fakultas Teknik

Sebelum membeli bahan-bahan tersebut, diperkirakan terlebih dahulu berapa jumlah yang dibutuhkan. Untuk agregat halus (pasir) diperhitungkan yang terbuang setelah pengayakan. Jumlah pasir dan koral dilebihkan, agar pemeriksaan agregat tidak terulang lagi, karena mengingat karakteristik agregat tidak akan sama untuk tiap pembelian. Semen di beli pada waktu mendekati hari pengecoran, karena penyimpanan semen yang terlalu lama akan mengurangi mutu jika penyimpanan yang kurang tepat dapat menyebabkan semen mengeras dan terjadi penggumpalan.

\section{Pemeriksaan Agregat}

Penggunaan agregat dalam beton mencapai $70 \%$ - $75 \%$ dari seluruh volume massa padat beton. Untuk mencapai kekuatan beton yang baik yang sesuai dengan yang direncanakan, maka perlu adanya pemeriksaan agregat.

\section{Pemeriksaan Agregat Halus}

Adapun pemeriksaan yang akan dilakukan untuk agregat halus yaitu berat jenis dan penyerapan, kadar lumpur dan lempung dan analisa ayak.

\section{Agregat Kasar}

Adapun pemeriksaan yang dilakukan pada agregat kasar yaitu berat jenis dan penyerapan dan analisa ayak.

\section{Pemeriksaan limbah pecahan batu bata}

Pada penelitian ini material pengganti agregat kasar yang digunakan adalah limbah 
pecahan batu bata yang dipotong - potong dengan ukuran $2 \mathrm{~cm}$ sampai $3 \mathrm{~cm}$ dengan desain pengganti agregat kasar 10\%, 20\%, $30 \%$, dari berat agregat kasar.

\section{E. Perencanaan Campuran Beton}

Metode perencanaan campuran beton yang digunakan dalam penelitian ini dengan menggunakan campuran beton dengan mutu beton rencana $\mathrm{fc}^{\prime} 16,9 \mathrm{MPa}$ (K.200). Dengan langkah kerja sebagai berikut :

1. Menentukan karakteristik kuat tekan yang disyaratkan diambil 16,9 $\mathrm{MPa}$ atau 200 $\mathrm{kg} / \mathrm{cm}^{2}$ pada umur 28 hari dengan jumlah cacat $5 \%$ dari banyak sample.

2. Menentukan deviasi standar (s) dengan melihat tabel.

3. Nilai tambah (margin) menggunakan rumus $=\mathrm{k} \times \mathrm{s}$.

4. Menghitung kekuatan rata-rata yang akan dicapai dengan menjumlahkan hasil nomor $1+3$.

5. Menetapkan jenis semen yang digunakan adalah semen Portland type I

6. Menetapkan jenis agregat yang dipakai adalah :

- Agregat halus : alami

- Agregat kasar : alam / batu pecah / split

7. Faktor air semen ditentukan dengan berpedoman pada grafik kemudian disesuaikan dengan type semen yang dipakai dan kekuatan tekan yang direncanakan pada umur 28 hari.

8. Faktor air semen maksimum dapat dilihat pada tabel yang disesuaikan dengan kondisi penggunaan beton tersebut.

9. Menentukan tinggi slump dengan menyesuaikan kegunaan dari beton tersebut untuk konstruksi.

10. Ukuran kadar agregat ditentukan dari hasil analisa saringan dengan mengambil ukuran agregat maksimum lolos saringan.

11. Kadar air bebas dapat dilihat pada tabel disesuaikan dengan besarnya slump dan ukuran agregat maksimum.

12. Kadar semen tiap $\mathrm{m}^{3}$ beton dihitung dari perbandingan air dengan faktor air semen (No. 11 / No.7 ).

13. Kadar semen maksimum tidak ditentukan jadi dapat diabaikan.

14. Kadar semen minimum ditetapkan 352 $\mathrm{kg} / \mathrm{m}^{3}$.

15. Susunan besar butir agregat disesuaikan dengan analisa saringan yang ditentukan.

16. Persentase agregat halus diperoleh dari perbandingan gabungan antara agregat halus dan kasar (lihat pada lampiran).

17. Berat jenis relatif agregat kering permukaan diperoleh dari perbandingan rata-rata berat jenis agregat halus dan kasar.

18. Berat jenis beton diperoleh dari grafik dengan jalan membuat grafik baru yang sesuai dengan nilai berat jenis gabungan.

19. Kadar agregat gabungan = berat jenis, beton dikurangi jumlah kadar semen dan kadar air.

20. Kadar agregat halus persentase agregat halus (No. 16) x kadar agregat gabungan (No. 19).

21. Kadar agregat kasar kadar agregat gabungan (No. 19) dikurangi kadar agregat halus (No. 20).

Dari langkah No.1 sampai No.21, didapat susunan campuran beton teoritis untuk tiap $1 \mathrm{~m}^{3}$ yaitu diperlukan semen sebanyak (No.2), air (No.11), pasir (No.20), koral (No.21).

Dalam perhitungan yang telah dilakukan, agregat halus dan agregat kasar dalam keadaan jenuh kering permukaan (SSD) maka apabila material yang ada dilapangan tidak jenuh kering permukaan harus dilakukan koreksi terhadap kebutuhan bahannya.

\section{F. Pengujian Slump}

Peralatan yang digunakan dalam pengujian slump ini adalah meteran dan Kerucut Terpancung.

Langkah-langkah pengerjaannya adalah sebagai berikut :

1. Kerucut terpancung dan pelat dibasahi dengan kain basah.

2. Letakkan kerucut terpancung di atas pelat.

3. Isi kerucut terpancung sampai penuh dengan beton segar dalam 3 lapisan, setiap, lapis berisi kira-kira $1 / 3$ kerucut terpancung tersebut. Setiap lapis dipadatkan dengan 25 kali tumbukan secara merata. Pada pemadatan, tongkat harus tepat masuk sampai lapisan bagian bawah tiap lapisan.

4. Setelah selesai pemadatan ratakan permukaan benda uji dengan tongkat, tunggu selama 30 detik dan dalam jangka waktu ini semua benda uji yang jatuh disekitar kerucut harus disingkirkan. 
5. Kemudian angkat kerucut secara perlahanlahan keatas secara tegak lurus.

6. Ukur slump yang terjadi dengan menentukan penurunan benda uji terhadap puncak kerucut terpancung.

Perhitungan : Besar Slump = Tinggi Penurunan Benda Uji

\section{G. Pengujian kuat tekan beton}

Pengujian kuat tekan beton ini bertujuan untuk mengetahui kuat tekan beton yang dibuat apakah telah sesuai dengan yang telah direncanakan. Peralatan yang digunakan adalah Timbangan dan Mesin Uji Kuat Tekan.

Langkah-langkah kerjanya adalah :

- Kubus beton yang di rendam atau di rawat setelah mencapai umur yang direncanakan maka beton tersebut diangkat dari perendaman. Kubus beton dikeringkan dari air kemudian ditimbang untuk mengetahui berat isi dari beton keras.

- Setelah itu dilakukan pengujian kuat tekan dengan menggunakan mesin uji kuat tekan.

- Pengujian kuat tekan dilakukan sampai beton tersebut tidak mampu lagi memikul beban yang diberikan oleh mesin penguji kuat tekan.

Jika sudah di dapat hasil pengujian kuat tekan maka langkah selanjutnya tinggal menganalisis seberapa kuat tekan yang didapat dari proporsi yang direncanakan.

\section{ANALISIS DAN PEMBAHASAN}

\section{A. Pemeriksaan Agregat Halus}

Pengujian laboratorium yang dilakukan untuk agregat halus meliputi berat isi gembur dan berat isi padat, analisa saringan, berat jenis dan penyerapan, kadar lumpur dan kadar air, agregat halus yang digunakan adalah pasir sungai musi.

Tabel 4.1. Berat isi gembur dan padat agregat halus

\begin{tabular}{|c|c|c|c|c|c|c|c|}
\hline \multirow{2}{*}{\multicolumn{2}{|c|}{ Kegiatan }} & \multicolumn{2}{|c|}{ I } & \multicolumn{2}{|c|}{ II } & \multicolumn{2}{|c|}{ III } \\
\hline & & Gembur & Padat & Gembur & Padat & Gembur & Padat \\
\hline \multirow[t]{2}{*}{ A } & Volume & 1893,1 & 1893,1 & 1893,1 & 1893,1 & 1893,1 & 1893,1 \\
\hline & Silinder & 3 & 3 & 3 & 3 & 3 & 3 \\
\hline \multirow[t]{2}{*}{ B } & Berat & 855 & 855 & 855 & 855 & 855 & 855 \\
\hline & Silinder & & & & & & \\
\hline \multirow[t]{3}{*}{$\mathrm{C}$} & Berat & 2924 & 3258 & 2920 & 3230 & 2914 & 3288,5 \\
\hline & Benda & & & & & & \\
\hline & Uji & & & & & & \\
\hline
\end{tabular}

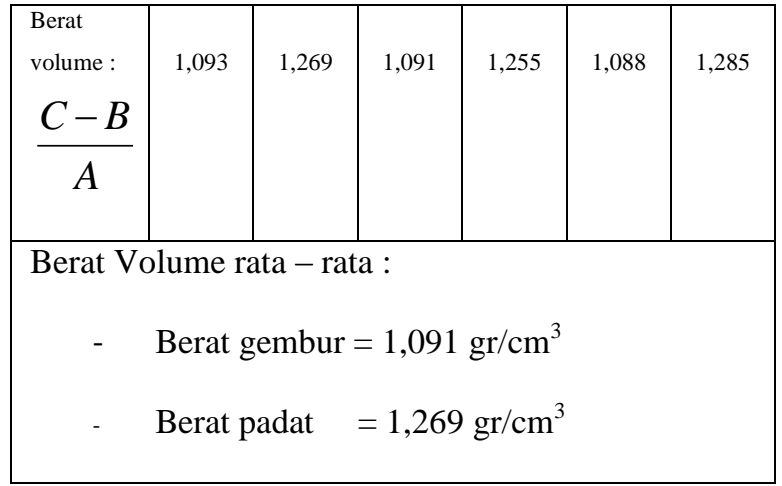

Tabel 4.2. Analisa Saringan Agregat Halus

\begin{tabular}{|c|c|c|c|c|}
\hline $\begin{array}{c}\text { Saringan } \\
(\mathrm{mm})\end{array}$ & $\begin{array}{c}\text { Berat } \\
\text { tertahan } \\
\end{array}$ & $\begin{array}{c}\text { Jumlah } \\
\text { berat }\end{array}$ & \multicolumn{2}{|c|}{$\begin{array}{c}\text { Jumlah persen } \\
\text { tertahan }\end{array}$} \\
\cline { 4 - 5 } & & & Tertahan & Lolos \\
\hline & & & & \\
4,75 & 0 & 0 & 0 & 100 \\
4 & 2 & 0,4 & 0,4 & 99,6 \\
2 & 4,5 & 0,9 & 1,3 & 98,7 \\
1 & 33 & 6,6 & 7,9 & 92,1 \\
0,5 & 30 & 6 & 13,9 & 86,1 \\
0,25 & 262,5 & 52,5 & 66,4 & 33,6 \\
0,125 & 153,5 & 30,7 & 97,1 & 2,9 \\
0,063 & 10 & 2 & 99,1 & 0,9 \\
Pan & 4,5 & 0,9 & 100 & 0 \\
\hline Total & 500 & 100 & 386,1 & \\
\hline
\end{tabular}

Angka Kehalusan $=\frac{386,1}{100}=3,861$

Tabel 4.3. Berat Jenis dan Penyerapan Agregat halus

\begin{tabular}{|l|l|c|c|}
\hline \multicolumn{2}{|c|}{ Kegiatan } & \multicolumn{2}{c|}{ Berat (gram) } \\
\cline { 3 - 4 } A & Berat cawan & I & II \\
B & Berat gelas ukur (1000 ml) & 869 & 881 \\
C & Berat gelas ukur + pasir + air & 303 & 303 \\
D & Berat gelas ukur + air & 1592,5 & 1594 \\
E & Berat cawan + pasir setelah & 1302 & 1302 \\
& dioven & 1367 & 1367 \\
Berat jenis kering : $\frac{E-A}{D+500-C}$ & 2,387 & 2,337 \\
\hline \multicolumn{2}{|c|}{ Bering Kerontang ) } & & \\
\hline
\end{tabular}




\begin{tabular}{|c|c|c|}
\hline $\begin{array}{l}\text { Persentase penyerapan air: } \\
\frac{500-(E-A)}{E-A}\end{array}$ & 2,669 & 2,881 \\
\hline $\begin{array}{l}\text { Berat jenis kering rata }- \text { rata }= \\
\text { Berat jenis SSD rata }- \text { rata }= \\
\text { Persentase penyerapan rata }- \text { rata }=\end{array}$ & & \\
\hline
\end{tabular}

Tabel 4.4. Kadar Lumpur Agregat halus

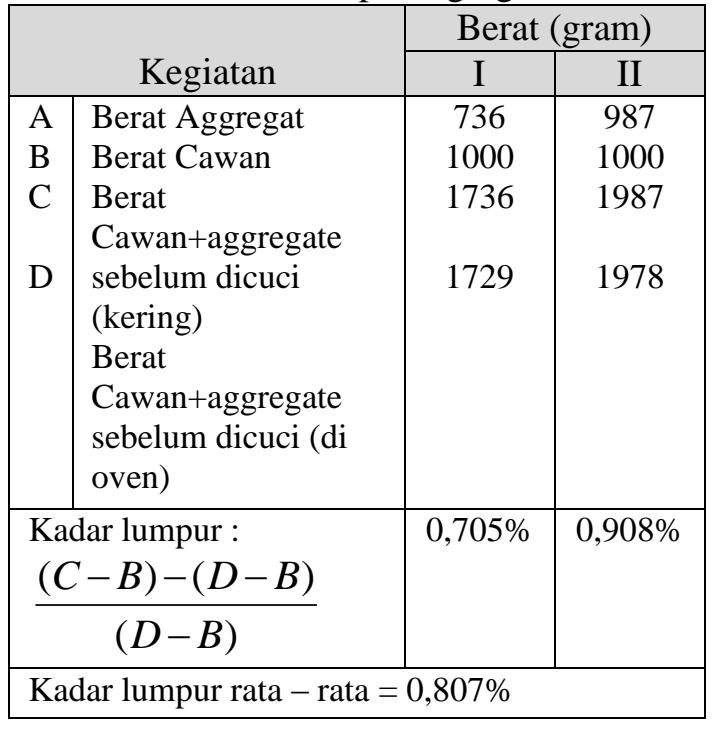

Tabel 4.5. Kadar Air Agregat halus

\begin{tabular}{|c|c|c|c|}
\hline \multirow{2}{*}{\multicolumn{2}{|c|}{ Kegiatan }} & \multicolumn{2}{|c|}{ Berat (gram) } \\
\hline & & \multirow{2}{*}{$\begin{array}{c}\mathrm{I} \\
815\end{array}$} & \multirow{2}{*}{$\frac{\text { II }}{82450}$} \\
\hline $\mathrm{A}$ & Berat Aggregat & & \\
\hline B & Berat Cawan & 3000 & 3000 \\
\hline $\mathrm{C}$ & Berat & 3815 & 3824,50 \\
\hline & Cawan+aggregat & & \\
\hline D & & 3616 & 3624,50 \\
\hline & Berat & & \\
\hline & Cawan+aggregate & & \\
\hline & oven) & & \\
\hline \multicolumn{2}{|c|}{$\begin{array}{l}\text { Kadar Lumpur: } \\
(C-A)-(D-A)\end{array}$} & $7,11 \%$ & $7,14 \%$ \\
\hline \multicolumn{2}{|r|}{$(D-A)$} & & \\
\hline \multicolumn{4}{|c|}{ Kadar air rata - rata $=7,13 \%$} \\
\hline
\end{tabular}

Tabel 4.6. Pemeriksaan Kadar Air Agregat

\begin{tabular}{|c|c|c|c|}
\hline \multicolumn{4}{|c|}{ Kasar } \\
\hline \multirow{2}{*}{\multicolumn{2}{|c|}{ Kegiatan }} & \multicolumn{2}{|c|}{ Berat (gram) } \\
\hline & & I & II \\
\hline $\mathrm{A}$ & Berat cawan $\left(\mathrm{W}_{1}\right)$ & 739 & 880 \\
\hline B & $\begin{array}{l}\text { Berat cawan + } \\
\text { Benda uji }\left(\mathrm{W}_{2}\right)\end{array}$ & 1511 & 1731 \\
\hline $\mathrm{C}$ & $\begin{array}{l}\text { Berat benda uji } \\
\left(\mathrm{W}_{3}=\mathrm{W}_{2}-\mathrm{W}_{1}\right)\end{array}$ & 772 & 851 \\
\hline D & $\begin{array}{l}\text { Berat cawan }+ \\
\text { Benda uji kering } \\
\text { oven }\left(\mathrm{W}_{4}\right)\end{array}$ & 1484 & 1700 \\
\hline $\mathrm{E}$ & $\begin{array}{l}\text { Berat benda uji } \\
\text { kering oven } \\
\left(\mathrm{W}_{5}=\mathrm{W}_{4}-\mathrm{W}_{1}\right)\end{array}$ & 745 & 820 \\
\hline F & $\begin{array}{l}\text { Kadar air agregat }= \\
\frac{W_{3}-W_{5}}{W_{5}} \times 100 \\
\%\end{array}$ & $3,624 \%$ & $3,780 \%$ \\
\hline \multicolumn{2}{|c|}{ Rata-Rata } & \multicolumn{2}{|c|}{$\frac{1}{3,702 \%}$} \\
\hline
\end{tabular}

Dari hasil pengujian kadar air agregat kasar didapat kan persentase sebesar 3,702\%

Tabel 4.7. Pemeriksaan Kadar Lumpur Agregat Kasar

\begin{tabular}{|c|c|c|c|}
\hline \multirow{2}{*}{\multicolumn{2}{|c|}{ Kegiatan }} & \multicolumn{2}{|c|}{ Berat (gram) } \\
\hline & & I & II \\
\hline $\mathrm{A}$ & Berat cawan $\left(\mathrm{W}_{1}\right)$ & 740 & 747 \\
\hline B & $\begin{array}{l}\text { Berat cawan }+ \\
\text { Benda uji }\left(\mathrm{W}_{2}\right)\end{array}$ & 1492 & 1401 \\
\hline $\mathrm{C}$ & $\begin{array}{l}\text { Berat benda uji } \\
\left(\mathrm{W}_{3}=\mathrm{W}_{2}-\mathrm{W}_{1}\right)\end{array}$ & 752 & 654 \\
\hline D & $\begin{array}{l}\text { Berat cawan }+ \\
\text { Benda uji kering } \\
\text { oven }\left(\mathrm{W}_{4}\right)\end{array}$ & 1467 & 1381 \\
\hline E & $\begin{array}{l}\text { Berat benda uji } \\
\text { kering oven } \\
\left(\mathrm{W}_{5}=\mathrm{W}_{4}-\mathrm{W}_{1}\right)\end{array}$ & 727 & 634 \\
\hline $\mathrm{F}$ & $\begin{array}{l}\text { Kadar air agregat }= \\
\frac{W_{3}-W_{5}}{W_{5}} \times 100 \\
\%\end{array}$ & $3,438 \%$ & $3,155 \%$ \\
\hline \multicolumn{2}{|c|}{ Rata-Rata } & \multicolumn{2}{|c|}{$3,297 \%$} \\
\hline
\end{tabular}

Dari hasil pengujian kadar air agregat kasar didapatkan persentase sebesar 3,297 \% 
Tabel 4.8. Pemeriksaan Berat Jenis dan Penyerapan

\begin{tabular}{|c|c|c|}
\hline Pemeriksaan & $\begin{array}{c}\text { I } \\
\text { (gram) }\end{array}$ & $\underset{\text { (gram) }}{\text { II }}$ \\
\hline $\begin{array}{l}\text { Berat benda uji jenuh permukaan kering } \\
\text { (Bj) }\end{array}$ & 500 & 500 \\
\hline Berat benda uji kering oven (Bk) & 485 & 494 \\
\hline Berat piknometer + air $\left(\mathrm{W}_{2}\right)$ & 1198 & 1200 \\
\hline Berat piknometer + Benda uji + air $\left(W_{1}\right)$ & 1492 & 1485 \\
\hline $\begin{array}{c}\text { Berat jenis kering }= \\
\qquad B K\end{array}$ & $2,354 \%$ & $2,298 \%$ \\
\hline$\left(W_{2}+500-W_{1}\right)$ & \multicolumn{2}{|c|}{ Rata - rata $=2,326$} \\
\hline $\begin{array}{c}\text { Berat jenis } \mathrm{SSD}= \\
\qquad B j\end{array}$ & $2,427 \%$ & $2,326 \%$ \\
\hline$\left(W_{2}+500-W_{1}\right)$ & \multicolumn{2}{|c|}{$\begin{array}{c}\text { Rata }- \text { rata }= \\
2,377\end{array}$} \\
\hline \multirow{2}{*}{ Penyerapan $=\frac{(B j-B k)}{B k} \times 100 \%$} & $3,093 \%$ & $1,215 \%$ \\
\hline & \multicolumn{2}{|c|}{$\begin{array}{c}\text { Rata }- \text { rata }= \\
2,154 \%\end{array}$} \\
\hline
\end{tabular}

Tabel 4.9. Pemeriksaan Berat Isi Gembur Agregat kasar

\begin{tabular}{|l|l|c|c|}
\hline \multicolumn{2}{|c|}{ Kegiatan } & \multicolumn{2}{c|}{ Berat (gram) } \\
\cline { 2 - 4 } A & Berat cawan $\left(\mathrm{W}_{1}\right)$ & 854 & II \\
B & $\begin{array}{l}\text { Berat cawan }+ \\
\text { Benda uji }\left(\mathrm{W}_{2}\right)\end{array}$ & 3212 & 5567 \\
$\mathrm{C}$ & $\begin{array}{l}\text { Berat benda uji } \\
\left(\mathrm{W}_{3}=\mathrm{W}_{2}-\mathrm{W}_{1}\right)\end{array}$ & 2358 & 3356 \\
$\mathrm{D}$ & $\begin{array}{l}\text { Volume cetakan } \\
(\text { V) }\end{array}$ & 1710,60 & 2493.46 \\
$\mathrm{E}$ & $\begin{array}{l}\text { Berat isi gembur } \\
\mathrm{W}_{3} / \mathrm{V}\end{array}$ & 1,38 & 1,35 \\
$\mathrm{~F}$ & $\begin{array}{l}\text { Berat isi gembur } \\
\text { rata-rata }\end{array}$ & 1,38 & 1,35 \\
\hline \multicolumn{2}{|c|}{$\begin{array}{l}\text { Berat isi gembur rata- } \\
\text { rata }\end{array}$} & $1,37 \mathrm{gr} / \mathrm{cm}^{3}$ \\
\hline
\end{tabular}

Tabel 4.10. Pemeriksaan Berat Isi Padat Agregat kasar

\begin{tabular}{|c|l|cc|}
\hline \multicolumn{2}{|c|}{ Kegiatan } & \multicolumn{2}{c|}{ Berat (gram) } \\
\cline { 2 - 4 } & I & II \\
\hline A & Berat cawan $\left(\mathrm{W}_{1}\right)$ & 854 & 2211 \\
B & Berat cawan + \\
C & Benda uji $\left(\mathrm{W}_{2}\right)$ & 3516 & 6038 \\
Berat benda uji & 2662 & 3827 \\
& $\left(\mathrm{~W}_{3}=\mathrm{W}_{2}-\mathrm{W}_{1}\right)$ & & \\
D & $\begin{array}{l}\text { Volume cetakan } \\
(\text { V) }\end{array}$ & 1710,60 & 2493.46 \\
E & $\begin{array}{l}\text { Berat isi Padat } \\
\text { W }\end{array}$ & 1,56 & 1,54 \\
\hline \multicolumn{2}{|l|}{ Berat isi padat rata-rata } & \multicolumn{2}{|c|}{$1,55 \mathrm{gr} / \mathrm{cm}^{3}$} \\
\hline
\end{tabular}

Dari hasil pemeriksaan berat isi agregat kasar, didapatkan berat isi agregat kasar rata - rata untuk keadaan gembur $=1,37$ $\mathrm{gr} / \mathrm{cm}^{3}$, sedangkan untuk berat isi agregat kasar rata - rata untuk keadaan padat $=1,55$ $\mathrm{gr} / \mathrm{cm}^{3}$

Tabel 4.11.. Pemeriksaan Analisa Saringan Agregat kasar

\begin{tabular}{|c|c|c|c|c|}
\hline \multirow{2}{*}{$\begin{array}{c}\text { Ukuran } \\
\text { Saringan } \\
(\mathrm{mm})\end{array}$} & \multicolumn{2}{|c|}{$\begin{array}{c}\text { Agregat } \\
\text { Tertahan }\end{array}$} & \multicolumn{2}{c|}{$\begin{array}{c}\text { Kumulatif } \\
\text { Agregat }\end{array}$} \\
\cline { 2 - 5 } & gram & $\%$ & Tertahan & Lolos \\
\hline 37,5 & 0 & 0 & 0 & 100 \\
\hline 19 & 11 & 0,37 & 0,37 & 99,63 \\
\hline 9,5 & 2477 & 82,56 & 82,93 & 17,07 \\
\hline 4 & 470 & 15,66 & 98,59 & 1,41 \\
\hline 2 & 2 & 0,07 & 98,66 & 1,34 \\
\hline 1 & 15 & 0,5 & 99,16 & 0,84 \\
\hline 0,5 & 5 & 0,17 & 99,33 & 0,67 \\
\hline 0,25 & 3 & 0,1 & 99.42 & 0,58 \\
\hline 0,125 & 2 & 0,07 & 99,5 & 0,5 \\
\hline 0,063 & 12 & 0,4 & 99,4 & 0,6 \\
\hline PAN & 3 & 0,1 & 100 & 0 \\
\hline Jumlah & $\mathbf{3 0 0 0}$ & $\mathbf{1 0 0}$ & $\mathbf{8 7 7 , 3 6}$ & \\
\hline \multicolumn{5}{|c|}{ Angka Kehalusan $=\frac{\text { Total \% kumulatif tertahan }}{4}$} \\
\multicolumn{5}{|c}{877,36} \\
\hline
\end{tabular}

Dari pemeriksaan yang telah dilakukan di laboratorium didapat data - data sebagai berikut :

1. Agregat Halus

Tabel 4.12. Data - data Pasir

\begin{tabular}{|c|l|l|}
\hline No & \multicolumn{1}{|c|}{ Uraian } & Keterangan \\
\hline 1 & Berat isi gembur & $1,091 \mathrm{gr} / \mathrm{cm}^{3}$ \\
\hline 2 & Berat Isi Padat & $1,269 \mathrm{gr} / \mathrm{cm}^{3}$ \\
\hline 3 & Berat jenis SSD & 2,427 \\
\hline 4 & Berat jenis kering & 2,362 \\
\hline 5 & Penyerapan & $2,775 \%$ \\
\hline 6 & Kadar Lumpur & $0,807 \%$ \\
\hline 7 & Kadar Air & $7,13 \%$ \\
\hline 8 & Gradasi Butiran & Zona 4 \\
\hline 9 & $\begin{array}{l}\text { Modulus } \\
\text { Kehalusan }\end{array}$ & 3,861 \\
\hline
\end{tabular}


2. Agregat Kasar

Tabel 4.13. Data - data kerikil

\begin{tabular}{|l|l|l|}
\hline No & \multicolumn{1}{|c|}{ Uraian } & Keterangan \\
\hline 1 & Berat isi gembur & $1,37 \mathrm{gr} / \mathrm{cm}^{3}$ \\
\hline 2 & Berat Isi Padat & $1,55 \mathrm{~kg} / \mathrm{cm}^{3}$ \\
\hline 3 & Berat jenis SSD & 2,377 \\
\hline 4 & Berat jenis kering & 2,326 \\
\hline 5 & Penyerapan & $2,154 \%$ \\
\hline 6 & Kadar Lumpur & $3,297 \%$ \\
\hline 7 & Kadar Air & $3,702 \%$ \\
\hline 8 & $\begin{array}{l}\text { Modulus } \\
\text { Kehalusan }\end{array}$ & 8,77 \\
\hline
\end{tabular}

Tabel 4.14. Daftar Isian (formulir) Perencanaan Campuran Beton

\begin{tabular}{|c|c|c|c|}
\hline No & Uraian & $\begin{array}{c}\text { Tabel / Grafik } \\
\text { Perhitungan }\end{array}$ & Nilai \\
\hline 1 & $\begin{array}{l}\text { Kuat tekan yang } \\
\text { diisyaratkan }\end{array}$ & $\begin{array}{l}\text { Ditetapkan } \\
\text { Ayat 3.3.1 }\end{array}$ & $\begin{array}{l}16,9 \mathrm{MPa} \text { pada } 28 \\
\text { hari bagian cacat } 5 \% \\
7,5 \mathrm{~N} / \mathrm{mm}^{2} \text { atau }\end{array}$ \\
\hline 2 & Deviasi Standar & Tabel 1 & tanpa data...N/mm $\mathrm{mm}^{2}$ \\
\hline 3 & $\begin{array}{l}\text { Nilai Tambah } \\
\text { (margin) }\end{array}$ & $\begin{array}{l}\text { Ayat } 3.3 .2( \\
1+3)\end{array}$ & $\begin{array}{l}(\mathrm{k}=1,64) 1,64 \times 7,5 \\
=12,3 \mathrm{~N} / \mathrm{mm}^{2}\end{array}$ \\
\hline 4 & $\begin{array}{l}\text { Kekuatan rata-rata } \\
\text { yang ditargetkan }\end{array}$ & Ditetapkan & $\begin{array}{l}22,5+12,3=34,8 \\
\mathrm{~N} / \mathrm{mm}^{2}\end{array}$ \\
\hline 5 & Jenis semen & Ditetapkan & Portland Type I \\
\hline 6 & $\begin{array}{l}\text { Jenis agregat : kasar } \\
\text { Jenis agregat : halus }\end{array}$ & & $\begin{array}{l}\text { Batu kerikil } \\
\text { Pasir }\end{array}$ \\
\hline 7 & $\begin{array}{l}\text { Faktor air semen } \\
\text { bebas }\end{array}$ & $\begin{array}{l}\text { Tabel } 2 \\
\text { Grafik1/2 }\end{array}$ & $\begin{array}{l}0,560 \text { (ambil nilai } \\
\text { yang terkecil) }\end{array}$ \\
\hline 8 & $\begin{array}{l}\text { Faktor air semen } \\
\text { maksimum }\end{array}$ & $\begin{array}{l}\text { Ditetapkan } \\
\text { Ayat } 3.3 .3\end{array}$ & 0,61 \\
\hline 9 & Slump & $\begin{array}{l}\text { Ditetapkan } \\
\text { Ayat 3.3.4 }\end{array}$ & Slump $60-100 \mathrm{~mm}$ \\
\hline 10 & $\begin{array}{l}\text { Ukuran agregat } \\
\text { maksimum }\end{array}$ & $\begin{array}{l}\text { Tabel } 6 \text { Ayat } \\
3.3 .5\end{array}$ & $\begin{array}{l}40 \mathrm{~mm} \\
215 \mathrm{~kg} / \mathrm{m}^{3}\end{array}$ \\
\hline 11 & Kadar air bebas & Tabel 4 & $215: 0,61=352$ \\
\hline 12 & Jumlah semen & $11: 8$ atau 7 & $\mathrm{~kg} / \mathrm{m}^{3}$ \\
\hline 13 & $\begin{array}{l}\text { Jumlah semen } \\
\text { maksimum }\end{array}$ & Ditetapkan & $352 \mathrm{~kg} / \mathrm{m}^{3}$ \\
\hline 14 & $\begin{array}{l}\text { Jumlah semen } \\
\text { minimum }\end{array}$ & $\begin{array}{l}\text { Ditetapkan } \\
\text { Ayat } \\
3.3 .2\end{array}$ & $75 \mathrm{~kg} / \mathrm{m}^{3}$ \\
\hline 15 & $\begin{array}{l}\text { Faktor air semen yang } \\
\text { disesuaikan }\end{array}$ & Ditetapkan & \\
\hline 16 & $\begin{array}{l}\text { Susunan besar butir } \\
\text { agregat halus }\end{array}$ & Grafik 3 s/d 6 & $\begin{array}{l}\text { Daerah gradasi } \\
\text { susunan butir IV }\end{array}$ \\
\hline 17 & Persen agregat halus & & 26 persen \\
\hline 18 & $\begin{array}{l}\text { Berat jenis relatif, } \\
\text { agregat } \\
\text { (kering permukaan) }\end{array}$ & & 2,473 \\
\hline 19 & Berat jenis beton & Grafik 13 & $2215 \mathrm{~kg} / \mathrm{m}^{3}$ \\
\hline 20 & $\begin{array}{l}\text { Kadar agregat } \\
\text { gabungan }\end{array}$ & $19-(12+11)$ & $\begin{array}{l}2215-(352+215) \\
=1.648 \mathrm{~kg} / \mathrm{m}^{3}\end{array}$ \\
\hline 21 & Kadar agregat halus & $\begin{array}{l}17 \times 20 \\
20-21\end{array}$ & $\begin{array}{l}1.648 \times 26 \%=429 \\
\mathrm{~kg} / \mathrm{m}^{3}\end{array}$ \\
\hline 22 & Kadar agregat kasar & & $\begin{array}{l}1.648-429=1.219 \\
\mathrm{~kg} / \mathrm{m}^{3}\end{array}$ \\
\hline
\end{tabular}

B. Koreksi Campuran Beton Normal

Tabel 4.15. koreksi campuran

\begin{tabular}{|c|c|c|c|c|c|}
\hline Uraian & $\begin{array}{c}\text { Semen } \\
\left(\mathrm{kg} / \mathrm{m}^{3}\right)\end{array}$ & $\begin{array}{c}\text { Pasir } \\
\left(\mathrm{kg} / \mathrm{m}^{3}\right)\end{array}$ & $\begin{array}{c}\text { Koral } \\
\left(\mathrm{kg} / \mathrm{m}^{3}\right)\end{array}$ & $\underset{\left(\mathrm{kg} / \mathrm{m}^{3}\right)}{\operatorname{Air}}$ & Total \\
\hline $\begin{array}{l}\text { Bahan } \\
\text { campuran untuk } \\
1 \mathrm{~m}^{3} \text { beton }\end{array}$ & 352 & 731 & 1031 & 215 & 2.329 \\
\hline Kadar air ( \% ) & - & - & - & - & - \\
\hline $\begin{array}{l}\text { Penyerapan } \\
\text { agregat ( \% ) }\end{array}$ & - & - & - & - & - \\
\hline $\begin{array}{l}\text { Air bebas } \\
\text { agregat }(\%)\end{array}$ & - & - & - & - & - \\
\hline $\begin{array}{l}\text { Air bebas } \times \\
\text { bebas agregat ( } \\
\mathrm{kg})\end{array}$ & - & - & - & - & - \\
\hline \multicolumn{5}{|c|}{ Total } & 2.329 \\
\hline
\end{tabular}

\section{Hasil pengujian slump beton}

Tabel 4.16. Nilai pengujian slump

\begin{tabular}{|c|c|}
\hline Beton & Nilai slump $(\mathrm{cm})$ \\
\hline Normal & 10 \\
\hline Pengganti Agregat Kasar 10\% & 8,3 \\
\hline Pengganti Agregat Kasar 20\% & 7 \\
\hline Pengganti Agregat Kasar 30\% & 6 \\
\hline
\end{tabular}

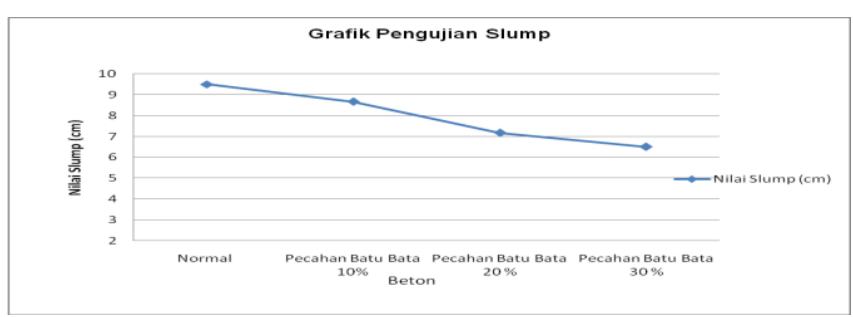

Berdasarkan grafik tersebut dapat diketahui bahwa slump yang dicapai mulai dari beton normal, beton dengan material limbah pecahan Batu Bata sebagai bahan pengganti agregat kasar 10\%, 20\%, 30\% masih memenuhi slump yang disyaratkan antara 60 $100 \mathrm{~mm}$.

Tabel 4.17. Rekapitulasi kuat tekan beton

\begin{tabular}{|l|c|c|c|c|}
\hline \multirow{2}{*}{$\begin{array}{c}\text { Kuat } \\
\text { tekan } \\
\text { beton } \\
\text { rata-rata }\end{array}$} & \multicolumn{4}{|c|}{ Variasi } \\
\cline { 2 - 5 } & Normal & $\begin{array}{l}\text { Pengganti } \\
\text { Agregat } \\
\text { Kasar 10 \% }\end{array}$ & $\begin{array}{l}\text { Pengganti } \\
\text { Agregat } \\
\text { Kasar 20 \% }\end{array}$ & $\begin{array}{l}\text { Pengganti } \\
\text { Agregat } \\
\text { Kasar 30 \% }\end{array}$ \\
\hline $\begin{array}{l}\text { Umur 7 } \\
\text { hari }\end{array}$ & 135,87 & 137,38 & 111,71 & 108,69 \\
\hline $\begin{array}{l}\text { Umur 14 } \\
\text { hari }\end{array}$ & 172,10 & 150,96 & 143,41 & 140,40 \\
\hline $\begin{array}{l}\text { Umur 21 } \\
\text { hari }\end{array}$ & 184,17 & 155,49 & 164,55 & 163,04 \\
\hline $\begin{array}{l}\text { Umur 28 } \\
\text { hari }\end{array}$ & 199,27 & 179,65 & 172,10 & 170,59 \\
\hline
\end{tabular}




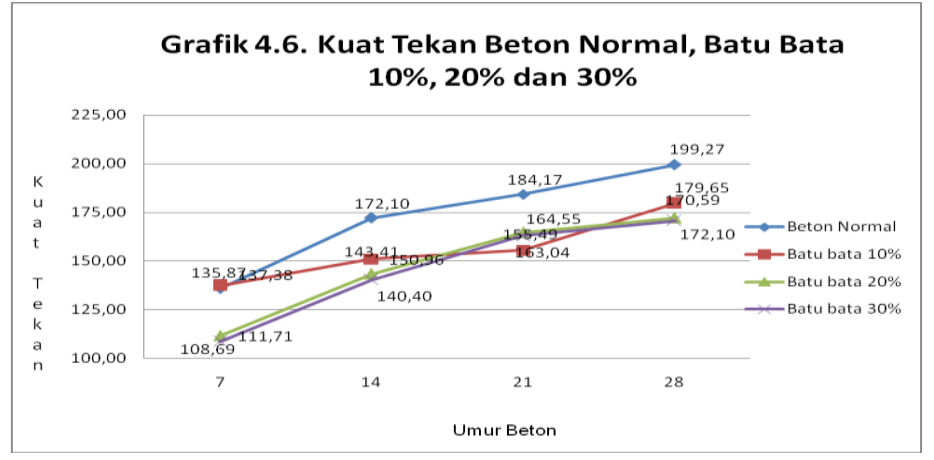

\section{PENUTUP}

\section{A. Kesimpulan}

Dari penelitian yang telah dilaksanakan dan dari hasil yang telah dicapai, penulis dapat menarik kesimpulan sebagai berikut :

$>$ Nilai evaluasi kuat tekan yang dicapai oleh beton tanpa menggunakan material pengganti agregat kasar atau beton normal pada umur 28 hari didapat kuat tekan $199,27 \mathrm{~kg} / \mathrm{cm}^{2}$.

$>$ Nilai evaluasi kuat tekan yang dicapai oleh beton dengan menggunakan limbah pecahan batu bata atau material pengganti agregat kasar $10 \%$ kuat tekan pada umur 28 hari didapat $179,65 \mathrm{~kg} / \mathrm{cm}^{2}$.

$>$ Nilai evaluasi kuat tekan yang dicapai oleh beton dengan menggunakan limbah pecahan batu bata atau material pengganti agregat kasar $20 \%$ kuat tekan pada umur 28 hari didapat $172,10 \mathrm{~kg} / \mathrm{cm}^{2}$.

$>$ Nilai evaluasi kuat tekan yang dicapai oleh beton dengan menggunakan limbah pecahan batu bata atau material pengganti agregat kasar $30 \%$ kuat tekan pada umur 28 hari didapat $170,59 \mathrm{~kg} / \mathrm{cm}^{2}$.

\section{B. Saran}

Setelah melakukan penelitian ini, penulis mempunyai saran yang mungkin dapat berguna bagi peneliti selanjutnya, yaitu :

$>$ Perlu dilakukan penelitian lanjutan dengan variasi persentase pengganti agregat kasar yang berbeda dan pengujian umur beton lebih dari 28 hari.

> Perhatikan umur rendaman benda uji, karena sangat berpengaruh pada waktu pengujian.

\section{DAFTAR PUSTAKA}

Imam Hanafi Hisbullah, 2016 "Pemanfaatan

Limbah Kaca Terhadap Bahan

Konstruksi Beton" Universitas Bakrie Jakarta.

Muhammad ikhsan Syaifuddin, Bambang Edison, Khairul Fahmi, 2013. Pengaruh Penambahan Campuran Serbuk Kayu Terhadap Kuat Tekan Beton. Fakutas Teknik Universitas Pasir Pengaraian.

Dept. Pekerjaan Umum, Tata Cara Perhitungan Harga Satuan Pekerjaan Beton (SNI DT-91-0008-2007).

Mulyono, T. 2003. Teknologi Beton. Andi: Yogyakarta.

SNI 03 - 2834-2000 "Tata Cara Pembuatan Campuran Beton Normal" Badan Standarisasi nasional (BSN) ICS 91.100 .30

Dipohusodo, I. 1999. Struktur Beton Bertulang Berdasarkan SK SNI-T-15-1991-03 Departemen Pekerjaan Umum RI. PT Gramedia Pustaka Utama : Jakarta.

Tjokrodimulyo, K. 1996. Teknologi Beton. Nafiri: Yogyakarta.

SNI 03 - 1974 - 1990 "Metode Pengujian Kuat Tekan Beton" Badan Standarisasi nasional (BSN) ICS 91.100.30 